\title{
Preparation technology of C100 High Strength Concrete
}

\author{
Wu Yanli ${ }^{1}$, Sun Jinlin ${ }^{2}$, Yin Suhua ${ }^{3 *}$ Liu Yu ${ }^{3}$ \\ ${ }^{1}$ HuangHe JiaoTong University Henan Jiaozuo, 454950; ${ }^{2}$ Southern China Zhengzhou Architectural Design \\ Co., Ltd., Zhengzhou 450000 \\ ${ }^{3}$ Hebei College of Industry and Technology, Shijiazhuang 050091, China; \\ $3^{*}$ E-mail: dongzhongqi@126.com
}

Keywords: High strength concrete f; cementitious material content; water cementitious ratio; compressive strength

Abstract: The effect of the cement amount, water cement ratio and sand ratio on compressive strength of $\mathrm{C} 100$ concrete was studied. The results show that the compressive strength of $\mathrm{C} 100$ concrete can reach $110 \mathrm{MPa}$ with the cement amount $600 \mathrm{~kg} / \mathrm{m} 3$, sand ratio $40 \%$ and water cementitious ratio 0.25 .

\section{Introduction}

With the application of steel structure in high-rise building is more and more widely, the application of concrete filled steel tube has gradually increased, low viscosity of super high strength concrete $(\mathrm{C} 100)$ because of its high specific strength and excellent performance, has been used in many modern civil engineering, especially in high-rise buildings. To study and master the preparation technology from the composition is very important. Concrete mixture, concrete is composed of cement paste and aggregate. In this paper, the concrete construction of Huangchao Wanxin mansion in Shenyang steel pipe as an example, the construction of production and application technology of C100 High strength concrete filled steel tube are analyzed.

\section{Raw materials and experimental methods}

The cementitious materials of cement, fly ash, slag, silica fume and beads; the workability of defoaming agent and superplasticizer; aggregate used in the test are of fine aggregate and coarse aggregate. The production of Qinhuangdao P, 42.5R cement, $28 \mathrm{~d}$ flexural strength of 9.0MPa. The compressive strength of $60.4 \mathrm{mpa}$; the fineness modulus of 3.1 coarse sand, and through the loop equipment washing, mud content is $0.9 \%$; the Fushun gravel, $5 \sim 20 \mathrm{~mm}$ continuous gradation, crushing index is $5.6 \%$; admixture, admixture, cz- type admixture and additive j1118t.

Table 1 is based on sand, stone water content, the benchmark mixture ratio is adjusted. The 'double mixing' technology, that is, superplasticizer and ultra-fine mineral admixture.

Table 1 mixture ratio of reference concrete $\mathrm{kg} / \mathrm{m}^{3}$

\begin{tabular}{ccc}
\hline Amount of cementitious material $\left(\mathrm{Kg} / \mathrm{m}^{3}\right)$ & Sand $(\%)$ & water to binder ratio (\%) \\
\hline 550 & 35 & 0.20 \\
600 & 40 & 0.25 \\
650 & 45 & 0.30 \\
700 & & \\
\hline
\end{tabular}

\section{Experimental result}

\subsection{Particle distribution of cementitious materials}

Figure 1 is a scanning electron microscope (SEM) analysis of cement, fly ash, mineral powder, silica fume and micro beads. The cement and mineral powders are amorphous particles with many 
edges and corners. Fly ash, silica fume and micro particles are all compact spheres.

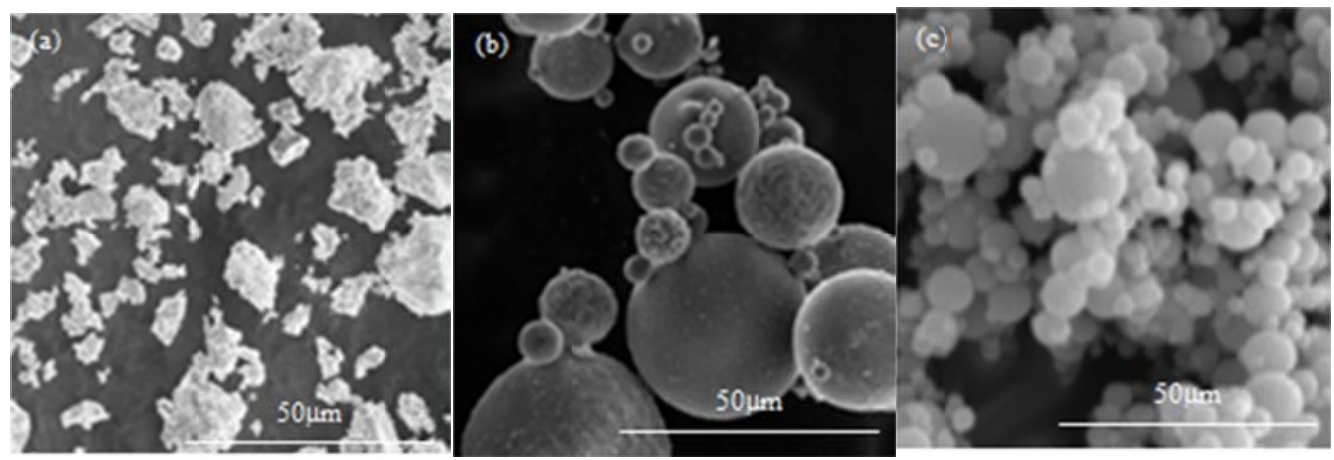

Fig. 1 cement, fly ash, mineral powder, silica fume and micro beads

\subsection{Effect of cementitious material on compressive strength of $\mathrm{C} 100$ concrete}

Table 2 is the four cement amount of $550 \mathrm{~kg} / \mathrm{m}^{3}, 600 \mathrm{~kg} / \mathrm{m}^{3}, 650 \mathrm{~kg} / \mathrm{m}^{3}$ and $730 \mathrm{~kg} / \mathrm{m}^{3}$, according to the ratio of water cement ratio is 0.25 with the concrete, sand ratio is $40 \%$, the use of class I fly ash, effect of cement amount on compressive strength, it can be seen that with the cement amount increased from $550 \mathrm{~kg} / \mathrm{m}^{3}$ to $700 \mathrm{~kg} / \mathrm{m}^{3}$ at different ages the compressive strength was increased, compressive strength of $28 \mathrm{~d}$ increased by $25 \mathrm{MPa} .90 \mathrm{~d}$ the compressive strength more than $113 \mathrm{MPa}$, cement amount is $700 \mathrm{~kg} / \mathrm{m} 3$ to $130 \mathrm{MPa}$. When the amount of adhesive used in $600-650 \mathrm{~kg} / \mathrm{m}^{3}$, the amount of cementitious material increases, and the strength tends to be stable

The above analysis shows that, with the increase of amount of cement, the compressive strength increased, but the increase in the cost of engineering application; cement amount $550 \mathrm{~kg} / \mathrm{m}^{3}, 28 \mathrm{~d}$ compressive strength is less than that of $110 \mathrm{MPa}$, does not meet the requirements of cement amount is greater than $600 \mathrm{~kg} / \mathrm{m}^{3}, 28 \mathrm{~d}$ compressive strength reached $110 \mathrm{MPa}$, considering the cost, the test of rubber concrete $\mathrm{C} 100$ the amount of material of $600 \mathrm{~kg} / \mathrm{m}^{3}$ was suitable.

Table 2 Effect of sizing agent on working performance and compressive strength of ultra high strength (C100) concrete

\begin{tabular}{cccccc}
\hline Glue dosage $\left(\mathrm{Kg} / \mathrm{m}^{3}\right)$ & $3 \mathrm{~d}(\mathrm{MPa})$ & $7 \mathrm{~d}(\mathrm{MPa})$ & $28 \mathrm{~d}(\mathrm{MPa})$ & $56 \mathrm{~d}(\mathrm{MPa})$ & $90 \mathrm{~d}(\mathrm{MPa})$ \\
\hline 550 & 80 & 87 & 104 & 111 & 116 \\
600 & 90 & 97 & 112 & 117 & 119 \\
650 & 92 & 99 & 112.5 & 121 & 127 \\
700 & 98.5 & 104 & 118 & 125 & 132 \\
\hline
\end{tabular}

\subsection{Effect of sand ratio on compressive strength of $\mathrm{C} 100$ concrete}

On the $37 \%, 40 \%, 43 \%$ and $46 \%$ of the four sand ratio of ultra high strength $(\mathrm{C} 100)$ of concrete workability and compressive strength. Ultra high strength (C100) concrete cement amount is $630 \mathrm{~kg} / \mathrm{m}^{3}$, the water cement ratio is 0.21 , the class I fly ash, were used to change the rate of sand so as to change the working performance and compressive strength the test, the test results as shown in table 3 .

Table 3 is the amount of four kinds of $600 \mathrm{~kg} / \mathrm{m}^{3}$ plastic materials, in accordance with the ratio in the water binder ratio of 0.25 with the concrete, the use of class I fly ash, 35\%, $40 \%$ and $45 \%$ of the three effect of sand ratio on the compressive strength of concrete C100. Figure 3 shows that the ultra high strength concrete $(\mathrm{C} 100)$ with the sand ratio increases, the age of during the period of compressive strength were first increased and then decreased. Ultra high strength concrete (C100) sand ratio is $40 \%$, the compressive strength reached the maximum compressive strength of $28 \mathrm{~d}$ $112 \mathrm{MPa}$, 90d $117 \mathrm{MPa}$. sand ratio increased from $40 \%$ to $45 \%$, the ageThe strength of the kiln is lower and the work performance is slightly improved. From the balance of the work performance and the strength, the sand rate is $40 \%$. 
Table 3 Effect of sand content on working performance and compressive strength of C100 ultra high strength concrete

\begin{tabular}{crrrrr}
\hline The water binder ratio & $3 \mathrm{~d}(\mathrm{MPa})$ & $7 \mathrm{~d}(\mathrm{MPa})$ & $28 \mathrm{~d}(\mathrm{MPa})$ & $56 \mathrm{~d}(\mathrm{MPa})$ & $90 \mathrm{~d}(\mathrm{MPa})$ \\
\hline 0.35 & 81 & 91.2 & 107 & 113 & 115 \\
0.40 & 90.1 & 95.2 & 112.5 & 113 & 118 \\
0.45 & 85.1 & 93 & 104.5 & 110 & 114 \\
\hline
\end{tabular}

\subsection{Effect of water binder ratio on compressive strength of $\mathrm{C100}$ concrete}

The water cement ratio are the main factors influencing the strength of concrete, water cement ratio $(>0.14)$ is lower, the higher the strength of concrete, called water binder ratio rule. This rule also applies to the super high strength concrete, because the lower the water binder ratio, the lower the porosity of concrete after hardening, but the intensity is higher. Low viscosity of super high strength concrete at the same time to consider the requirements for the performance of the concrete. Therefore, in order to prepare super high strength concrete, the experiment adopted 0.23 below the water binder ratio is $0.19,0.2,0.21$ and 0.22 . (C100) ultra high strength concrete cement amount is $630 \mathrm{~kg} / \mathrm{m}^{3}$, the sand rate is $40 \%$, the use of I grade fly ash, are used to change the water binder ratio, thereby changing the compressive strength and work performance, test matching, such as table 3-4 shows that the test results shown in Figure 4.

Figure 2 for ultra high strength (C100) variation of compressive strength and working performance of concrete with water binder ratio. By 3-6 (a) shows that gas content in similar circumstances (1\%-1.3\%), ultra high strength concrete $(\mathrm{C} 100)$ with the increase of water cement ratio, expansion degree increased, T50 and V the funnel and tube collapsed time were decreased. With the increase of water cement ratio, concrete slump and slump increases, when the water binder ratio is 0.22 , the slump and slump reached the maximum; while T50 and V down all the time in the funnel and tube water binder ratio is 0.22 reaches the maximum, respectively $6 \mathrm{~S}$ and $35 \mathrm{~S}$ and $5.5 \mathrm{~s}$. content of cementitious materials under certain conditions, the size of the water cement ratio determines the water consumption per unit volume and paste volume and paste volume per unit volume is determined the main factors of fresh concrete fluidity. Therefore water cement ratio of fresh concrete the performance of the work is very obvious.

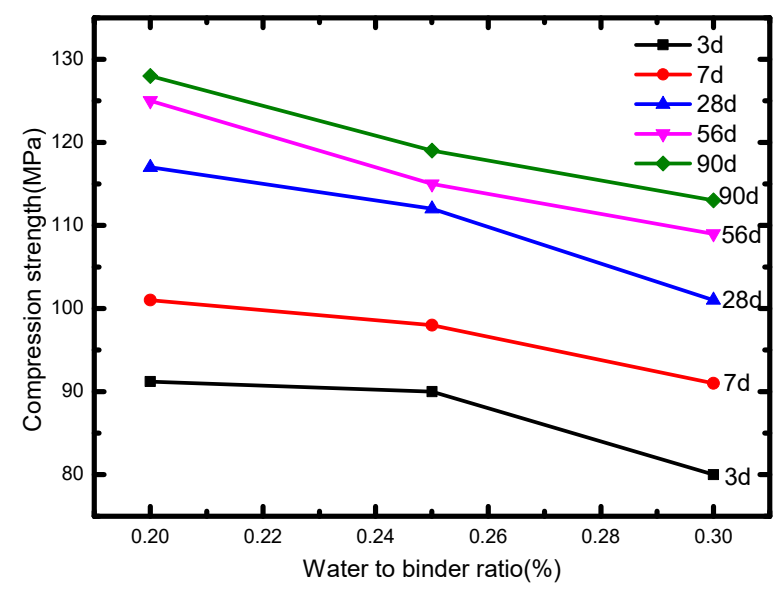

Fig. 2 Effect of water binder ratio on working performance and compressive strength of ultra high strength $(\mathrm{C} 100)$ concrete

Figure 4 is the amount of four kinds of $600 \mathrm{~kg} / \mathrm{m}^{3}$ plastic materials, sand ratio $40 \%$, water cement ratio is $0.20,0.25$ and 0.30 , the compressive strength of concrete $\mathrm{C} 100$. Figure 5 shows that the ultra high strength (C100) decreases the compressive strength of concrete at each stage were decreased with the increase of water cement ratio, water cement ratio is mainly due to the greater the harmful hole formed more hydration process in concrete, plays a harmful effect on the strength of concrete. 
When water cement ratio is 0.25 , the compressive strength of $\mathrm{C} 100$ concrete can reach $110 \mathrm{mpa}$.

\section{Conclusion}

(1) A requirements of raw materials into the plant, has a strict control of relevant indicators. The C100 concrete sand for machine washing treatment, the mud content dropped to $0.9 \%$, working on C100 concrete, plasticity and strength plays an important role.

(2) To set production, transport station that person, car, fixed pump, ensure the relative independence of $\mathrm{C} 100$ concrete production, transportation, to accurately perform the key function of mixture ratio and quality control.

(3) The work of C100 concrete is good, hard to ensure the pumping construction. At the same time, to meet the surrounding steel airtight, internal reinforcement that required vibration inconvenience factors such as good fluidity.

(4) The design of C100 steel tube concrete preparation strength $120 \mathrm{MPa}$, compressive strength of the actual total average value is $119.1 \mathrm{mpa}$, the maximum compressive strength of the 10 batch of $28 \mathrm{~d}$ statistics difference $3.3 \mathrm{Mpa}$, the standard deviation range. To prove the whole production, construction process control the system has achieved good results.

\section{Acknowledgements}

This work is financially supported by Project supported by the Hebei provincial key research and development program (16214526), Hebei Provincial Higher Education Fund for science and Technology (QN2016006) and the project of Hebei Industrial University (ZY2016009)

\section{References}

[1] Qian Jiaru, Lin Liyan, Wang Zhan,et ai. Technical specification for steel tube-reiforced concrete column structure [M].The outline of the eleventh fiver-year plan for national economic \& social development of the people's republic of china profile, 2005, Beijing.

[2] Lin Jinsheng, Wu Xinzhi, Chen Anmin, et al. Construction technology of Guangzhou new TV tower [J]. Construction Techoloy, 2009, 38 (3): 9-14.

[3] Zhong Shantong. Steel-concete composite structure of skyscraper [M].Guangzhou: South China University of Technology Press,2003.(in Chinese)

[4] Wang Jiansheng. Supervising points during steel tube conctete construction [J].Shanxi Architecture, 2008, 34(2):242-243.(in Chinese)

[5] Building construction manual (4th edition)[M].Beijing: China Architecture \& Building Press,2003.(in Chinese) 